\title{
Assessing the Suitability of Surface Water for Domestic Purposes in Uburu; Southeast of Nigeria
}

\author{
Babatunde, O.A and Umahi, C. C \\ Department of Chemistry, Nigerian defence Academy, Kaduna, Kaduna State, Nigeria
}

\begin{abstract}
The quality of surface water used for domestic purposes in Uburu, Ohaozara Local Government area, Ebonyi State, South-East of Nigeria were analyzed. The physicochemical analysis was carried out from water samples collected from river Ogwu, Akawo and Ihenu in December 2012 using standard method. The mean values were found to be $17.06 \pm 0.08 \mathrm{NTU}, 19.00 \mathrm{NTU}$ and $21.00 \mathrm{NTU}$ for turbidity, $149.20 \pm 0.39,156.65$ \pm 0.72 and $142.04 \pm 0.76 \mathrm{mg} / \mathrm{L}$, for chloride, while the mean values for sodium is $546.09 \pm 0.68,532.76 \pm 0.48$ and $581.14 \pm 0.84 \mathrm{mg} / \mathrm{L}$ and $10.21 \pm 0.02,10.34 \pm 0.050$ and $12.45 \pm 0.33 \mathrm{mg} / \mathrm{L}$ is for potassium for the three rivers respectively All other value for electrical conductivity, temperature, $p H$, alkalinity, calcium hardness, magnesium hardness, total hardness, total dissolved solids, total solids, dissolved oxygen, sulphate ions, nitrate ions, calcium ions, and magnesium ions were also within the permissible limits. The mean values obtained from physicochemical analysis were compared with WHO standards for drinking and domestic water.
\end{abstract}

Keywords: Water quality, Surface water, Uburu Rivers

\section{Introduction}

Water is one of the most important natural resources useful for developmental purposes in both urban and rural areas. It is vital to our existence in life therefore thorough physico-chemical examinations are conducted on surface and underground water. Most of the rural communities in the developing countries lack access to potable water supply. They rely commonly on rivers, streams, wells and ponds for daily domestic purpose (WHO, 2000). However world Health Organization (WHO, 1993) reported that water from most of these sources are contaminated, yet they are used directly by the inhabitants. One of the targets of the millennium development goals (Millenium Development Goal) in terms of healthy living for the masses can be achieved through the supply of safe and convenient water. Hence, analysis of water for physical, chemical properties including heavy metals are very important for public health studies (Osuinde and Enuezie, 1999; WHO, 2006). The study intends to carry out the physical and chemical analysis of the selected rivers in Uburu in ohaozara local government area of Ebonyi state. Since the populace depends on the rivers for domestic purposes, there is the need to assess the quality of the water and extent of contamination of these rivers for the suitability of the water for domestic purpose.

\section{STUDY AREA}

Uburu a town located in ohozara local government area of Ebonyi state and is comprised of forteen villages. It is known for its famous salt deposits stretching from Ihenu, Amata, amenu, umuchima and urobo communities. Uburu is primarily bestowed with salt lakes also known as brine, silicon dioxide, gelina (lead sulphate), zinc sulphate and sandstone. It is bound in the south by Abakiliki South. Ohaozara local government is characterized by tropical climate with distinct wet and dry seasons. The rivers flow down from Enugu hill down to nkerefi into Uburu and to efuna then to cross river before it empties into the Atlantic.

\section{Materials And Methods}

\section{Reagents:}

All analysis was made with distilled water and all chemicals used were os analytical grade and were used without further purification. $\mathrm{HNO}_{3}, \mathrm{HCl}$,EDTA etc were purchased from $\mathrm{BDH}$ chemical company.

\section{Sample Collection/ Sample Preservation}

Fifteen water samples were collected in clean plastic bottles from river Ogwu, Akawo and Ihenu. The surface water samples were collected at one week intervals for a period of one month in December 2012 using composite sampling method.

Each sample was stored in a clean bottle with screw cap that has been pre-washed with $\mathrm{HNO}_{3}$ and thoroughly rinsed with distilled water (Parson et al., 2001 and Johnstone 1995).

\section{Sample Analysis}

The temperature, $\mathrm{pH}$, electrical conductivity, turbidity and dissolved oxygen of the surface water 
samples were determined in situ with a portable thermometer, $\mathrm{pH}$ meter (H1991301) and conductivity meter (H1991301), turbidity meter, DO meter respectively. While others such as total dissolve solids (TDS), Salinity, total solids, alkalinity, BOD, total hardness, sulphate, chloride, nitrate, calcium, magnesium, potassium and sodium were analyzed using APHA, 2012.

\section{Digestion of water samples for metal ion determination}

The water sample was digested using nitric acid. $100 \mathrm{~cm}^{3}$ of the water samples was transferred into a beaker and $5 \mathrm{~cm}^{3}$ of concentrated $\mathrm{HNO}_{3}$ was added. The content was heated to evaporation with the content to about $20 \mathrm{~cm}^{3}$. This was allowed to cool and another $5 \mathrm{~cm}^{3}$ concentrated $\mathrm{HNO}_{3}$ was added and this was covered with watch glass and placed on a hot plate. Small portions of $\mathrm{HNO}_{3}$ were added continuously to the solution until the solution appears to be light coloured and clear. The sample was then filtered and the volume was adjusted to $100 \mathrm{~cm}^{3}$ with distilled water (APHA, 1995). The concentration of potassium (K), sodium (Na), and calcium $(\mathrm{Ca})$, magnesium $(\mathrm{Mg})$ were determined using atomic absorption spectrophotometer AAS (VGB Buck Scientific model 210).The essence of the digestion before the analysis was to reduce organic matter interference and convert metal to a form that can be analyzed by AAS.

\section{Results}

The mean value and standard deviation of the physicochemical parameters determined in river ogwu

\begin{tabular}{|c|c|c|c|c|c|c|}
\hline PARAMETERS & UNITS & WHO & Min & $\operatorname{Max}$ & Mean & $\begin{array}{l}\text { Standard } \\
\text { deviation }\end{array}$ \\
\hline Temperature & ${ }^{\circ} \mathrm{C}$ & 35.00 & 23.60 & 27.80 & 25.68 & 1.65 \\
\hline Turbidity & NTU & 5.0 & 17.00 & 17.20 & 17.06 & 0.08 \\
\hline $\mathrm{pH}$ & & $6.5-8.5$ & 6.69 & 6.91 & 6.78 & 0.09 \\
\hline Electrical Conductivity & $\mu \mathrm{S} / \mathrm{cm}$ & 500.00 & 410.00 & 416.00 & 413.40 & 2.41 \\
\hline Alkalinity & $\mathrm{mg} / \mathrm{L}$ & 100.0 & 26.00 & 28.73 & 27.76 & 0.97 \\
\hline Total Solids & $\mathrm{mg} / \mathrm{L}$ & 500.00 & 267.30 & 274.60 & 271.10 & 3.19 \\
\hline Total Dissolved Solids & $\mathrm{mg} / \mathrm{L}$ & 500.00 & 250.00 & 257.00 & 252.40 & 2.79 \\
\hline Total Hardness & $\mathrm{mg} / \mathrm{L}$ & 120.00 & 23.00 & 25.00 & 23.80 & 0.77 \\
\hline Salinity & $\mathrm{g} / \mathrm{L}$ & & 27.00 & 27.00 & 27.00 & \\
\hline Dissolved Oxygen & $\mathrm{mg} / \mathrm{L}$ & $>4$ & 5.10 & 5.40 & 5.24 & 0.13 \\
\hline BOD & $\mathrm{mg} / \mathrm{L}$ & 0 & 4.96 & 5.28 & 5.10 & 2.42 \\
\hline Calcium & $\mathrm{mg} / \mathrm{L}$ & 50.00 & 20.04 & 20.86 & 20.45 & 035 \\
\hline Magnesium & $\mathrm{mg} / \mathrm{L}$ & 50.00 & 0.92 & 1.15 & 1.17 & 0.09 \\
\hline Sodium & $\mathrm{mg} / \mathrm{L}$ & 200.00 & 545.50 & 546.30 & 546.09 & 0.68 \\
\hline Potassium & $\mathrm{mg} / \mathrm{L}$ & 0.50 & 10.18 & 10.24 & 10.21 & 0.02 \\
\hline Chlorides & $\mathrm{mg} / \mathrm{L}$ & 200.0 & 138.55 & 139.50 & 139.04 & 0.39 \\
\hline Sulphates & $\mathrm{mg} / \mathrm{L}$ & 200.0 & 53.43 & 55.90 & 54.63 & 1.09 \\
\hline Nitrate & $\mathrm{mg} / \mathrm{L}$ & 3.0 & 0.25 & 0.25 & 0.25 & 0 \\
\hline
\end{tabular}

The mean value and standard deviation of the physicochemical parameters determined in river akawo

\begin{tabular}{|l|l|l|l|l|l|l|}
\hline PARAMETERS & UNITS & WHO & Min & Max & Mean & $\begin{array}{l}\text { Standard } \\
\text { deviation }\end{array}$ \\
\hline Temperature & ${ }^{\circ} \mathrm{C}$ & 35.00 & 29.50 & 31.60 & 30.82 & 0.85 \\
\hline Turbidity & $\mathrm{NTU}$ & 5.0 & 19.00 & 19.00 & 19.00 & 0 \\
\hline $\mathrm{pH}$ & & $6.5-8.5$ & 7.33 & 7.75 & 7.47 & 0.17 \\
\hline Electrical Conductivity & $\mathrm{MS} / \mathrm{cm}$ & 500.00 & 431.00 & 469.00 & 452.00 & 13.78 \\
\hline Alkalinity & $\mathrm{mg} / \mathrm{L}$ & 100.0 & 29.10 & 31.20 & 30.01 & 0.73 \\
\hline Total Solids & $\mathrm{mg} / \mathrm{L}$ & 500.00 & 185.35 & 199.55 & 193.07 & 6.29 \\
\hline Total Dissolved Solids & $\mathrm{mg} / \mathrm{L}$ & 500.00 & 98.00 & 99.00 & 98.60 & 0.54 \\
\hline Total Hardness & $\mathrm{mg} / \mathrm{L}$ & 120.00 & 21.00 & 26.70 & 21.90 & 0.65 \\
\hline Salinity & $\mathrm{g} / \mathrm{L}$ & & 23.00 & 23.00 & 23.00 & 0 \\
\hline Dissolved Oxygen & $\mathrm{mg} / \mathrm{L}$ & 4 & 7.05 & 7.10 & 7.07 & 0.02 \\
\hline BOD & $\mathrm{mg} / \mathrm{L}$ & 0 & 5.40 & 7.80 & 6.12 & 0.88 \\
\hline Calcium & $\mathrm{mg} / \mathrm{L}$ & 50.00 & 22.10 & 22.70 & 22.28 & 0.24 \\
\hline Magnesium & $\mathrm{mg} / \mathrm{L}$ & 50.00 & 1.61 & 1.69 & 1.66 & 0.03 \\
\hline Sodium & $\mathrm{mg} / \mathrm{L}$ & 200.00 & 532.40 & 533.60 & 532.76 & 0.48 \\
\hline Potassium & $\mathrm{mg} / \mathrm{L}$ & 0.50 & 10.29 & 10.40 & 10.34 & 0.05 \\
\hline Chlorides & $\mathrm{mg} / \mathrm{L}$ & 200.0 & 155.98 & 157.82 & 156.65 & 0.72 \\
\hline
\end{tabular}


Assessing The Suitability Of Surface Water For Domestic Purposes In Uburu; Southeast Of Nigeria

\begin{tabular}{|l|l|l|l|l|l|l|}
\hline Sulphates & $\mathrm{mg} / \mathrm{L}$ & 200.0 & 36.41 & 39.05 & 37.04 & 1.20 \\
\hline Nitrate & $\mathrm{mg} / \mathrm{L}$ & 3.0 & 1.15 & 1.15 & 1.15 & 0 \\
\hline
\end{tabular}

The mean value and standard deviation of the physicochemical parameters determined in River Ihenu

\begin{tabular}{|c|c|c|c|c|c|c|}
\hline PARAMETERS & UNITS & WHO, 2000 & Min & Max & Mean & $\begin{array}{l}\text { Standard } \\
\text { deviation }\end{array}$ \\
\hline Temperature & ${ }^{\circ} \mathrm{C}$ & 35.00 & 27.40 & 30.60 & 29.22 & 1.24 \\
\hline $\mathrm{pH}$ & & $6.5-8.5$ & 6.93 & 7.20 & 7.01 & 0.11 \\
\hline Electrical Conductivity & $\mu \mathrm{S} / \mathrm{cm}$ & 500.00 & 406.00 & 417.00 & 412.60 & 4.28 \\
\hline Total Dissolved Solids & $\mathrm{mg} / \mathrm{L}$ & 500.00 & 154.00 & 159.00 & 156.40 & 2.07 \\
\hline Total Hardness & $\mathrm{mg} / \mathrm{L}$ & 120.00 & 41.00 & 49.00 & 47.40 & 1.50 \\
\hline Salinity & $\mathrm{g} / \mathrm{L}$ & & 33.00 & 33.00 & 33.00 & 0 \\
\hline Dissolved Oxygen & $\mathrm{mg} / \mathrm{L}$ & $>4$ & 5.10 & 5.30 & 5.17 & 0.07 \\
\hline BOD & $\mathrm{mg} / \mathrm{L}$ & 0 & 6.00 & 9.00 & 7.20 & 1.47 \\
\hline Sodium & $\mathrm{mg} / \mathrm{L}$ & 200.00 & 580.10 & 582.00 & 581.14 & 0.84 \\
\hline Potassium & $\mathrm{mg} / \mathrm{L}$ & 0.50 & 11.86 & 12.65 & 12.45 & 0.33 \\
\hline Chlorides & $\mathrm{mg} / \mathrm{L}$ & 200.0 & 141.20 & 143.25 & 142.04 & 0.76 \\
\hline Sulphates & $\mathrm{mg} / \mathrm{L}$ & 200.0 & 42.13 & 49.56 & 43.86 & 3.24 \\
\hline Nitrate & $\mathrm{mg} / \mathrm{L}$ & 3.0 & 1.15 & 1.15 & 1.15 & 0 \\
\hline
\end{tabular}

\section{Discussion}

Tables 1, 2 and 3, showed the quality water from river Ogwu, Akawo and Ihenu respectively. The $\mathrm{pH}$ value range from 6.69 - 7.16 with mean concentration of $6.78 \pm 0.09$ for River Ogwu, the value for River Akawo ranged from 6.93-7.20 with mean concentration of 7.01 \pm 0.11 for River Ihenu and 7.33-7.75 with mean concentration of $7.47 \pm 0.17$ for River Akawo. These fall within the acceptable limit of 6.5-8.5 (WHO, 2005). The $\mathrm{pH}$ result also agrees with the report of mendie, 2005 which indicates that large majority of surface water supplies may register a pH range between 6.9.-7-4. The water samples ranged from slightly acidic to slightly alkaline. The electrical conductivity values ranged from $410-416 \mu \mathrm{S} / \mathrm{cm}$ with mean concentration of $413.40 \pm$ $2.41 \mu \mathrm{S} / \mathrm{cm}$ for river Ogwu. River Akawo values ranged from 431.00-469.00 $\mu \mathrm{S} / \mathrm{cm}$ with mean concentration of $452 \mu \mathrm{S} / \mathrm{cm}$, the values recorded for River Ihenu ranged from 406.00-417.00 $\mu \mathrm{S} / \mathrm{cm}$ with a mean concentration of $412.60 \pm 2.28 \mu \mathrm{S} / \mathrm{cm}$. The temperature for river Ogwu, Akawo and Ihenu were recorded in tables 1, 2 and 3 as $25.68 \pm 0.85{ }^{\circ} \mathrm{C}, 30.82 \pm 1.65{ }^{\circ} \mathrm{C}, 29.22 \pm 1.24{ }^{\circ} \mathrm{C}$. High temperature is known to exert a major influence on the biological activity and growth of aquatic organism, fish, insect, zooplankton and other aquatic species decreases until finally there are a few. Also some compounds are more toxic to aquatic life, the rate of their chemical reaction increases in high temperature. An increase in temperature also exacerbates low dissolve oxygen level; it encourages the microbial breakdown of organic matter, a process that requires dissolved oxygen (USEPA, 2005). Water with higher temperature may be saturated with oxygen but still do not contain enough oxygen for aquatic life (Michaud, 1991). In water above $30^{\circ} \mathrm{C}$ a suppression of all benthic organisms can be expected (James et al., 1979).

The salinity values recorded in tables 1,2 and 3, was $27.00 \mathrm{~g} / \mathrm{L}, 33.00 \mathrm{~g} / \mathrm{L}, 23.00 \mathrm{~g} / \mathrm{L}$, for river Ogwu, river Akawo and river Ihenu respectively. High salinity has an impact on the people and industries reliant on water, It reduces crop yields, It makes the land unsuitable for agricultural purposes, it increases the hardness of water (Alan, 1994).In industry, high levels of dissolved salts can cause corrosion, scale, and poor steam quality and increase the need for chemicals for water treatment (Munns, 2002). The alkalinity of the surface water with mean concentration are $26.00-28.73 \mathrm{mg} / \mathrm{L}$ with mean concentration of $(27.76 \pm 0.97) \mathrm{mg} / \mathrm{L}, 29.10-31.20 \mathrm{mg} / \mathrm{L}$ with mean concentration of $30.01 \pm 0.73 \mathrm{mg} / \mathrm{L}, 35.30-37.57 \mathrm{mg} / \mathrm{L}$ with mean concentration of $36.50 \pm 0.75$ $\mathrm{mg} / \mathrm{L}$ for Rivers Ogwu, Akawo and Ihenu respectively. The total solids value for the surface water sample recorded in tables 1, 2 and 3, were 267.30- $274.60 \mathrm{mg} / \mathrm{L}, 257.00-276.00 \mathrm{mg} / \mathrm{L}$ and $185.35-199.55 \mathrm{mg} / \mathrm{L}$ for Rivers Ogwu, Akawo and Ihenu repectively.. High concentration of total solids in river can lower water quality and cause water balance problem for individual organism. The total hardness recorded in tables 1, 2 and 3 were 23.00-25.00 mg/L with mean concentration of $23.80 \pm 0.77 \mathrm{mg} / \mathrm{L}, 41.00-49.00 \mathrm{mg} / \mathrm{L}$ with mean concentration $47.40 \pm 1.50 \mathrm{mg} / \mathrm{L}, 21.00-26.70 \mathrm{mg} / \mathrm{L}$ with mean concentration of $21.90 \pm 0.65 \mathrm{mg} / \mathrm{L}$ for Rivers Ogwu, Akawo and Ihenu respectively. The water is not hard. The TDS values were $250.0 \mathrm{mg} / \mathrm{L}, 154.0 \mathrm{mg} / \mathrm{L}$ and $98.0 \mathrm{mg} / \mathrm{L}$ for rivers Ogwu, Akawo and Ihenu respectively. The maximum values were $257 \mathrm{mg} / \mathrm{L}$ and $159 \mathrm{mg} / \mathrm{L}$ for rivers 
Ogwu and Akawo.

Chloride values ranged from $138.55-139.50 \mathrm{mg} / \mathrm{L}, 141.20-143.25 \mathrm{mg} / \mathrm{L}, 155.98-157.82 \mathrm{mg} / \mathrm{L}$ for rivers Ogwu, Akawo and Ihenu respectively with mean concentration of $139.20 \pm 0.39 \mathrm{mg} / \mathrm{L}$. The sulphate values ranged from $53.43-55.90 \mathrm{mg} / \mathrm{L}$ with mean concentration of $54.63 \pm 1.09 \mathrm{mg} / \mathrm{L}, 35.92-39.05 \mathrm{mg} / \mathrm{L}$ with mean concentration of $37.004 \pm 1.20$ and $41.63-49.56 \mathrm{mg} / \mathrm{l}$ with mean concentration of $43.86 \pm 3.24$ for rivers Ogwu, Akawo and Ihenu respectively. Nitrate values recorded were $0.25 \mathrm{mg} / \mathrm{L}, 1.15 \mathrm{mg} / \mathrm{L}$ and $1.15 \mathrm{mg} / \mathrm{L}$ repsectively. These values are all below the maximum permissible limits of National Drinking Water standards and WHO standards (WHO, 2005). Enrichment of Nitrate can be attributed to human and animal sewage, intense use of fertilizers and harmattan dust during dry season (Vomocil, 1987) that are washed into water bodies by rainfall. The magnesium value recorded for the Rivers ranged between $0.92-1.15 \mathrm{mg} / \mathrm{L}, 1.25-2.00$ $\mathrm{mg} / \mathrm{L}$ and $1.61-1.69 \mathrm{mg} / \mathrm{L}$ respectively. Their mean values were recorded as $1.002 \pm 0.009 \mathrm{mg} / \mathrm{L}, 1.66 \pm 0.03$ $\mathrm{mg} / \mathrm{L}$ and $1.55 \pm 0.28 \mathrm{mg} / \mathrm{L}$ respectively. These values are below the permissible limits of WHO guidelines for magnesium content in water but side effects are unlikely because negative human and animal health effects are not expected, The calcium ion value for the three rivers ranged from $20.04-20.86 \mathrm{mg} / \mathrm{L}, 14.40-15.50 \mathrm{mg} / \mathrm{L}$, $22.10-22.70 \mathrm{mg} / \mathrm{L}$ respectively.

The turbidity of the water samples recorded in tables 1, 2 and 3, shows 17.0-17.20 NTU, 21.00 NTU, 19.00 NTU for rivers Ogwu, Akawo and Ihenu respectively. The increase in turbidity in the three rivers is possibly due to effects of runoff water which carries with it several compounds (bacteria, suspended solids, hydrocarbon and heavy metals). These compounds can impede the rays of light entering the river. This effect can influence the dissolved oxygen level in water bodies because suspended particles absorb light and increase the temperature of water and this reduces the oxygen level of the water. The more, turbid water, is the greater the chances of water borne disease. This is because contaminants like bacteria viruses can become attached to these suspended particles and are protected by these solid from disinfection by chlorination or Ultra-violet sterilization (USEPA, 2005). The values of potassium recorded with their mean concentration were, 10.18$10.24 \mathrm{mg} / \mathrm{L},(10.21 \pm 0.02) \mathrm{mg} / \mathrm{L}, 10.29-10.40 \mathrm{mg} / \mathrm{L},(10.34 \pm 0.05) \mathrm{mg} / \mathrm{L}, 11.86-12.59 \mathrm{mg} / \mathrm{L},(12.45 \pm 0.33)$ $\mathrm{mg} / \mathrm{L}$ for rivers Ogwu, Akawo and Ihenu repsectively. Potassium intoxication by ingestion is rare because potassium is rapidly excreted in the absence of pre- existing kidney damage and large single doses usually induce vomiting as reported by Gosselin et al, 1984. The sodium concentration for the three rivers with their mean concentration were $545.50-546.30 \mathrm{mg} / \mathrm{L}$ with $546.09 \pm 0.68 .581 .10-582.0 \mathrm{mg} / \mathrm{L}$ with $581.14 \pm 0.84$ $\mathrm{mg} / \mathrm{L}$ and $532.40-533.60 \mathrm{mg} / \mathrm{L}$ with $532.76 \pm 0.48 \mathrm{mg} / \mathrm{L}$ respectively. All the values recorded are above the permissible limits of WHO (WHO, 2005) for the three rivers. It shows that the three rivers are contaminated with turbidity, potassium and sodium. High exposure to potassium could result in health effects in people with kidney disease, heart disease, coronary artery disease, hypertension, diabetes. Sodium is to be expected where there has been increase in road salt (Jackson and Jobbagy, 2005). An increase in sodium in surface water above natural level may indicate pollution or salt intrusion in the case of Uburu town. It could also be as a result of salt deposits in Uburu. It may indicate the presence of pathogens or other contaminants present in the surface water which may cause adverse health effects. Excess sodium intake causes heart failure, kidney stone, oedema, stroke, gastric ulcer and osteoporosis. Low sodium can lead to electrolyte imbalance, which can cause severe or fatal neurological problems (Jensen, 1997).

\section{Conclusion}

The study has examined the physical and chemical analysis of River Ogwu, Akawo and Ihenu in Ohozara local Government area of Ebonyi state. The results obtained showed that the turbidity of the three rivers were above WHO limits. Sodium and potassium ions were very high and were above the WHO critical limits. The high sodium value can be attributed to the presence of salt deposits in Uburu and can be a major reason why the river is salty. Excess sodium intake can result to heart failure, kidney stone, oedema and stroke. Some of these cases are seen in individuals living in Uburu community. Suitable measures have to be taken to minimize the load of salts in the soil, so that fertility could be maintained and better yield may be obtained. All other parameters fall within the WHO permissible limits for drinking and domestic water quality. From the result, it is concluded that the rivers are fairly polluted

\section{Reference}

[1]. Alan, D. (1994). Soil salinity and salt tolerance of horticultural and landscape plant.

[2]. APHA (1995). Standard Methods for the Examination of Water and Wastewater nineteenth edition, American Public Health Association. Washington D.C

[3]. APHA (2012). Standard Methods for the Examination of Water and Wastewater twenty second edition, American Public Health Association. Washington D.C

[4]. Blaurock, B (1996). Minerals and Trace Element Analysis ( $2^{\text {nd }}$ Edition). Pp. 1150-2050.

[5]. Dada, O.O., Okuofu, C.A., and Obele, E. (1990a). Fecal pollution of well water in Zaria City, Nigeria, Savannah 10: 1-5.

[6]. Dada, O.O., Okuofu, C.A. and Yusuf, Z. (1990b). The relationship between residual chlorine and bacteriological quality of tap water in the water distribution system of Zaria Nigeria. Savannah 10 (2): 95 -101. 
[7]. Gosselin, R.E, Smith, R.P and Hodge, H.C.1984. Clinical toxicology of commercial products $5^{\text {th }}$ edition. Williams and Wilkins, Baltimore, MD.

[8]. Jackson, R. B, Jobbagy, E.G, 2005. From Icy roads to salty streams. Proc National Academy, science U.S.A, 2005, 102, $14487-$ 14488 .

[9]. Jensen, B.D.C (1997). Come Alive. Total Health through an Understanding of Minerals, Trace Elements and Electrolyte. 12: 200 205.

[10]. Mendie, U. (2005). The nature of water in: the theory and practice of clean water production for domestic and industrial use in Lagos: (4 ${ }^{\text {th }}$ Edition) lacto-medals publishers, PP: $1-21$.

[11]. Michaud, T. P (1991). A Citizen Guide to Monitoring and Understanding Lakes and Streams. Publ. 94-149. Washington State Department of Ecology, Publication office Olympia, WA, USA (360) 407-74-72.

[12]. Munns, R. (2002) Comparative physiology of salt and water stress. Plant Cell Environ. 25: 239-250.

[13]. Osuinde, M.I and Eneuzi, N.R. (1999). "Bacteriological analysis of ground water" Nigeria Journal of Microbiology 13:47-54

[14]. Parsons, T. R, Maits Y and Lalli: C. M (2001). A Manual of Chemical and Biochemical Methods for Sea Water Analysis Pergamum Press New York Pp.212.

[15]. United State Environmental Protection Agency (USEPA) (2005). 'Protecting water quality from Agricultural runoff' Fact sheet No. EPA-841-F-05-001.

[16]. WHO (World Health Organization) (1993). Guidelines for drinking water quality. $2^{\text {nd }}$ Edition. 1:130.

[17]. WHO (World Health Organization) (2000). Harzadous Chemicals in Human and Environmental Health: a Resource Book for School, College and University students. World Health Organization, Geneva, Document No WHO. 564-R-14-101

[18]. WHO (World Health Organization) (2005). Guidelines for drinking water quality. $1^{\text {st }}$ to first to third Edition. 1

[19]. WHO (2006) Guidelines for safe recreational water environments vol. 2. Swimming pools and similar environments. Geneva, World Health Organization, Water, Sanitation and Health. 